\title{
Coping with flood risk adaptation in Mediterranean countries: evidences, uncertainties, strategies and limits
}

\author{
María-Carmen Llasat ${ }^{1, a}$, Montserrat Llasat-Botija ${ }^{1}$, María Cortès ${ }^{1}$, Tomeu Rigo ${ }^{2}$, Anna del Moral ${ }^{1}$, Isabel Caballero ${ }^{1}$, \\ Ana iglesias ${ }^{3}$ and José A. Jiménez ${ }^{4}$ \\ ${ }^{1}$ Department of Applied Physics, University of Barcelona, c) Martí Franqués 1, Barcelona, 08028, Spain \\ ${ }^{2}$ Meteorological Service of Catalonia, Barcelona, Spain \\ ${ }^{3}$ Department of Agricultural Economics \& CEIGRAM, Technical University of Madrid, Spain \\ ${ }^{4}$ Laboratori d'Enginyeria Maritima, Universitat Politècnica de Catalunya, BarcelonaTech, c/Jordi Girona 1-3, Campus Nord ed. D1, \\ Barcelona, 08034, Spain
}

\begin{abstract}
Hydrometeorological risks are the most important natural hazard in the world. Among them, flood risk is the one that affects more population and causes the greatest damages. Their mitigation and adaptation to the impact that climate change has on them is a priority in most government agendas. However, recent reports and papers still show significant uncertainty associated with their future development. Uncertainty is still higher when we consider the interaction with society and the changes in vulnerability. Therefore, they need to be treated from a holistic perspective that integrates bottom-up (from impact and vulnerability) and top-down (from hazard) approaches in the same methodology. Besides this, the Hyogo and Sendai protocols developed by UNISDR insist in the development of adaptation measures through the improvement in risk awareness and resilience. This communication shows a holistic approach to cope with flood risk in adaptation planning, the different tools and procedures for a better empowerment of the population, and the limits of the different adaptation measures when the impact of climate change is considered. The study is focused in Catalonia located in the east of the Iberian Peninsula.
\end{abstract}

\section{Introduction}

Floods are the most frequent natural risk in the Mediterranean region and the one that generates the most economic losses. Since 1900, river flooding has caused to the Mediterranean Area more than 85 billion Euros on damages (EM-DAT, http://www.emdat.be/). However, although flood damages are increasing (CRED-UNISDR, 2015) flood observations show the contrary in some regions. In effect, Blöschl et al. (2019) have defined regional patterns in Europe based on the most complete database of European flooding for the period 1960-2010, and they have obtained for the South of Europe a decreasing flood trend in medium and large catchments due to decreasing precipitation and increasing evaporation. Particularly, in Spain, the change in mean annual flood discharge per decade is between -5 and $-12 \%$. This divergence between trends observed in maximum flood discharge and damages can be associated with other parameters like exposure and vulnerability. However, in the case of the Mediterranean countries there is another important factor. Damages caused by floods in this region are usually related to flash floods that are much more frequent than in the rest of Europe, affecting mainly the coast, where population and urban settlements are rapidly increasing in flood-prone areas (Gaume et al., 2016). Flash floods usually affect small and torrential catchments without gauging stations. Consequently, the estimations of floods are based on their impacts and are not included in databases like EM-DAT or Munich Reinsurance (Llasat et al., 2013a). In this regard, a detailed analysis shows an increase in impacts since 1981 in regions of Italy, France and Spain (Llasat et al., 2013b). Those flash floods are produced by heavy convective rains, usually local and short lasting. Llasat et al. (2016) found in the NE of Spain a little signal on the increase of convective precipitation concentrated in less events, while Tramblay and Somot (2018) found significantly increasing trends on extreme daily precipitation in Northern Mediterranean catchments for the RCP4.5 and RCP8.5 scenarios from the EuroCORDEX experiment. All these results point to a potential decrease in river floods but an increase in torrential flashfloods within the Mediterranean Region. This fact, together with the socioeconomic and land-use changes in the region, make a difficult prognosis on flood impacts evolution.

In this context, this paper shows a holistic approach to cope with flood risk in adaptation planning in coastal areas, a range of different tools and procedures for a better empowerment of the population, and the limits of the

\footnotetext{
${ }^{\mathrm{a}}$ Corresponding author: author@e, $\mathrm{e}-\mathrm{mail} . \mathrm{org}$

DOI 10.3311/FLOODRisk2020.12.20
} 
different adaptation measures when the impact of climate change is considered. The present work has been developed in the framework of the Spanish project MCostAdapt that deals with the "Adaptation pathways to Climate Change in the Spanish Mediterranean coastal zone. Beyond adaptability limits".

The contribution departs from a state of the art focused on the analysis of human and socioeconomic impacts, based on which, the philosophy, strategies and tactics to improve flood risk reduction, and their inclusion in adaptative planning is built. Potential strategies and main constraints are analyzed, distinguishing between structural measures, non- structural measures and natural based solutions, and having in mind the flood risk perception and the role of citizens. As a case study the manuscript is centered on the Northeast of the Iberian Peninsula, where more than 258 flood events have been recorded between 1981 and 2015 in Catalonia alone, resulting in 117 fatalities (Petrucci et al., 2019).

\section{Analysis of flood impacts for a holistic approach to flood study}

The main factors involved in flood risk analysis are (Field et al., 2012):

- the hazard: the likelihood of a natural phenomenon causing damage

- the vulnerability: the propensity to be adversely affected, including questions such sensitivity or susceptibility to damage and the lack of response capacity and adaptation.

- the exposure: the presence of people or human activities in places that could be adversely affected

- the resilience: the ability of a system and its components to anticipate, absorb, accommodate, or recover from the effects of a hazardous event in a timely and efficient way, including ways optimizing the essential basic structures and functions.

Most scientific works in the subject consider the risk of flooding whether from a "top-down" perspective, or from a hazard approach: departing from the nature of the phenomenon (rainfall or discharge), other factors are underestimated such as the exposed assets (i.e. Borga et al., 2008; Blöschl et al., 2019). However, during the last years a different approach is emerging, where impacts, vulnerability and exposure are the main elements in building the framework for analysis. This approach based on the study of floods from impacts is called "bottom-up" (Garcia et al., 2014), and the limited availability of data is one of its main characteristics, becoming a challenge for researchers (i.e. Amaro et al., 2010; Petrucci et al., 2019). The bottom-up approach requires information of the damages. These can be categorized as direct (those that happen when there is physical contact between the water and people, properties or other objects) and indirect (those that take place outside the flood event in time and space). Besides, the two types of damages can be labelled as tangible or non-tangible, depending on whether it is possible or not to be valued in economic terms. Most studies consider exclusively direct and tangible damages. However, non-tangible and indirect ones are essential in order to get a whole picture of the impact's evaluation caused by natural disasters (Petrucci, 2013).

The last decade has seen an increase in articles dealing with flooding from both perspectives (i.e. Merz et al., 2012, 2013; Hall et al., 2014), mostly within the IAHS decade Panta Rhei "Change in Hydrology and society "(Montanari et al., 2013) and specifically within initiatives such as Flood Risk Change (i.e. Kreibich et al., 2017). This has resulted in numerous variables and indicators to characterize the different components of the problem which have been used in both two approaches. Tables 1 to 5 summarize hazard and damage (direct, indirect, tangible and non-tangible) indicators used in different research works (Thieken et al. 2005; Petrucci and Pasqua 2009; Llasat et al. 2009; Elmer et al. 2010; Amaro et al. 2010; Neumayer and Barthel 2011; Petrucci et al. 2012; EscuderBueno et al. 2012; Petrucci 2013; Nasiri and Shahmohammadi-Kalalagh, 2013; Merz et al. 2013; Llasat et al. 2013a, 2013b; Barbería et al. 2014; Schröter et al. 2014; Gain et al. 2015; Papagiannaki et al. 2015; Cortès et al. 2017; Dottori et al. 2018):

\begin{tabular}{|c|c|}
\hline Damage Indicator & Threshold/definition \\
\hline Precipitation & $\begin{array}{l}\text { Maximum precipitation in } 24 \mathrm{~h} \text {, peak } \\
\text { precipitation, mean precipitation per } \\
\text { basin, } \% \text { of precipitation higher than the } \\
\text { monthly mean, etc. }\end{array}$ \\
\hline $\begin{array}{l}\text { Precipitation } \\
\text { intensity }\end{array}$ & $\begin{array}{l}\text { Accumulated precipitation over } 1 \mathrm{~h}, 30 \\
\text { min (i.e.) or another time interval. }\end{array}$ \\
\hline Affected area & $\begin{array}{c}\text { IDA=affected area/total area; Number of } \\
\text { affected municipalities }\end{array}$ \\
\hline Event duration & $\begin{array}{c}\text { Number of days of the meteorological } \\
\text { event }\end{array}$ \\
\hline Flood duration & $\begin{array}{l}\text { Number of days or hours that the area } \\
\text { remains flooded }\end{array}$ \\
\hline Wind & $\begin{array}{l}\text { Coincidence of the flood event with } \\
\text { strong wind }\end{array}$ \\
\hline Depth of water & Water level \\
\hline Flooded surface & $\begin{array}{c}\text { Flooded area, or percentage related to } \\
\text { the total }\end{array}$ \\
\hline Flow & $\begin{array}{c}\text { Peak flow, unitary flow, peak flow/mean } \\
\text { flow }\end{array}$ \\
\hline $\begin{array}{l}\text { Contamination } \\
\text { indicator }\end{array}$ & $\begin{aligned} \text { From } 0= & \text { no contamination to } 6=\text { high } \\
& \text { contamination }\end{aligned}$ \\
\hline $\begin{array}{l}\text { Return period and } \\
\text { probability of } \\
\text { occurrence }\end{array}$ & $\begin{array}{l}\text { Precipitation, precipitation intensity, } \\
\text { flow, maximum discharge, flood volume }\end{array}$ \\
\hline Wetness index & $\begin{array}{c}\text { Number of consecutive precipitation } \\
\text { days before the flood event }\end{array}$ \\
\hline
\end{tabular}

Table 1. Different damage indicators, definition and considered thresholds.

The use of this information and these indicators depends of its availability. In Mediterranean countries it is difficult to have detailed information on damages and insurance data that pertain to private companies. In the case of Spain, the only source that provides economic data on damages (usually, aggregated damages) is the Consorcio de Compensación de Seguros (CCS, State Insurance Company). Despite its usefulness, this database is not designed to be used for this type of analysis, so it

[Type here] 
requires considerable additional work to take advantage of its existence.

\begin{tabular}{|c|c|}
\hline $\begin{array}{l}\text { Direct and tangible } \\
\text { damage Indicator }\end{array}$ & Threshold/definition \\
\hline Public buildings & Hospitals, schools, city councils, etc. \\
\hline Private buildings & Private houses with one or more floors \\
\hline $\begin{array}{c}\text { Immovable property } \\
\text { affected }\end{array}$ & $\begin{array}{l}\text { Affected buildings; bridges; } \mathrm{km} \text { of } \\
\text { roads; hectares of agriculture affected }\end{array}$ \\
\hline Loss ratio & Loss in buildings rate \\
\hline Bridges & $\begin{array}{c}\text { Bridges and footbridges affected by the } \\
\text { event }\end{array}$ \\
\hline $\begin{array}{c}\text { Hydraulic } \\
\text { infrastructures }\end{array}$ & $\begin{array}{l}\text { Windmills, irrigation channels, } \mathrm{km} \text { of } \\
\text { affected dykes }\end{array}$ \\
\hline $\begin{array}{c}\text { Communication } \\
\text { routes }\end{array}$ & Roads, highways, railways \\
\hline Vehicle & $\begin{array}{l}\text { Vehicles washed away or damaged by } \\
\text { water }\end{array}$ \\
\hline Productive activities & $\begin{array}{l}\text { Industry, agriculture and livestock, } \\
\text { commerce, tourist infrastructures }\end{array}$ \\
\hline $\begin{array}{c}\text { Emergency } \\
\text { management }\end{array}$ & $\begin{array}{c}\text { Hours of emergency tasks; } \mathrm{N}^{\circ} \text { of calls to } \\
112 ; \mathrm{N}^{\mathrm{o}} \text { of fire service operations }\end{array}$ \\
\hline $\begin{array}{c}\text { Requests received } \\
\text { by the meteorological } \\
\text { services }\end{array}$ & $\begin{array}{l}\text { Number of reports that the population } \\
\text { requests from the meteorological } \\
\text { service }\end{array}$ \\
\hline Cleaning & Cleaning tasks \\
\hline $\begin{array}{l}\text { Damages by type of } \\
\text { land use }\end{array}$ & $\begin{array}{l}\text { Damage in agriculture, infrastructure, } \\
\text { residences, commercial sector, } \\
\text { industries }\end{array}$ \\
\hline Insurance Data & $\begin{array}{c}\text { Aggregated or disaggregated } \\
\text { information }\end{array}$ \\
\hline
\end{tabular}

Table 2. Direct and tangible damage indicators, definition and/or considered thresholds.

\begin{tabular}{|c|c|}
\hline $\begin{array}{c}\text { Direct and non- } \\
\text { tangible damage } \\
\text { Indicator }\end{array}$ & Threshold/definition \\
\hline Deaths & Serious and slightly injured \\
\hline Injured & Number of evacuees due to flooding \\
\hline Evacuees & $\begin{array}{c}\text { Population or population density for a } \\
\text { given precipitation value; population } \\
\text { with a runoff value greater than a given } \\
\text { value; population in impermeable soil; } \\
\text { density of population or total population } \\
\text { in an affected region, etc }\end{array}$ \\
\hline
\end{tabular}

Table 3. Direct and non-tangible damage indicators, definition and/or considered thresholds.

The availability of two different databases, sourced by the GAMA (Meteorological Hazards Analysis Team), has helped detect those flood events that have affected the region of study and to apply some indicators of Tables 1 and 2:

- INUNGAMA (Barnolas and Llasat, 2007): include reports of the flood events occurred in Catalonia during the period 1900-2015, in different levels (municipal, county and basin), and including hydrometeorological data, impacts caused, and the affected areas.

- PRESSGAMA (Llasat et al., 2009): mainly based on press data and other data sources such as official reports. This database includes more than 15,000 news items, with a special mention to those provided at the natural risks and climate change section of the newspaper La Vanguardia (since 1981).

\begin{tabular}{|c|c|}
\hline $\begin{array}{c}\text { Indirect and } \\
\text { tangible damage } \\
\text { Indicator } \\
\end{array}$ & Threshold/definition \\
\hline Productive activities & Agriculture, business, tourism, etc. \\
\hline Services cuts & Gas, electricity, telephone lines, water \\
\hline Transit & $\begin{array}{c}\text { Losses due to traffic interruptions; loss } \\
\text { of working hours, etc. }\end{array}$ \\
\hline Public transport & Transport cuts \\
\hline $\begin{array}{c}\text { Accommodation of } \\
\text { the affected } \\
\text { population }\end{array}$ & $\begin{array}{l}\text { According to the period of } \\
\text { accommodation and the number of } \\
\text { people accommodated }\end{array}$ \\
\hline $\begin{array}{l}\text { Restoration of initial } \\
\text { conditions }\end{array}$ & $\begin{array}{l}\text { Construction and restoration of affected } \\
\text { buildings, retaining walls, opening of } \\
\text { alternative routes, cleaning of affected } \\
\text { roads }\end{array}$ \\
\hline Job losses & $\begin{array}{c}\text { Number of people without job due to } \\
\text { flooding }\end{array}$ \\
\hline GDP & Variation rate \\
\hline
\end{tabular}

Table 4. Indirect and tangible damage indicators, definition and/or considered thresholds.

\begin{tabular}{|c|c|}
\hline $\begin{array}{c}\text { Indirect and non- } \\
\text { tangible damage } \\
\text { Indicator }\end{array}$ & Threshold/definition \\
\hline Psychological effects & $\begin{array}{c}\text { Due to loss of a family member, injury } \\
\text { of a family member, prolonged condition } \\
\text { of displaced people, temporary condition } \\
\text { of displaced people, loss of personal } \\
\text { belongings, use of alternative roads, } \\
\text { public services inefficiency, temporary } \\
\text { traffic delay }\end{array}$ \\
\hline Illness & $\begin{array}{c}\text { Propagation of diseases, contaminated } \\
\text { water }\end{array}$ \\
\hline $\begin{array}{c}\text { Loss of trust in } \\
\text { authorities }\end{array}$ & $\begin{array}{c}\text { Severe criticism for emergency and } \\
\text { recovery management }\end{array}$ \\
\hline $\mathrm{N}^{\circ}$ of news & Number of news related to the event \\
\hline
\end{tabular}

Table 5. Indirect and non-tangible damage indicators, definition and/or considered thresholds.

\section{The area of study}

The region of interest is Catalonia, placed NE of the Iberian Peninsula (Fig. 1). It has an area of near 32,000 $\mathrm{km}^{2}$, with a complex topography and a meteorology modulated by the Mediterranean Sea. As it has been mentioned previously, Catalonia, like many other Mediterranean regions, is affected by floods every year that cause severe damages. Furthermore, the high dense population of coastal areas, together with the infrastructure and industries located near the ocean, makes these regions prone to suffer important damages.

Two examples of vulnerable areas are presented in this analysis: The Metropolitan Area of Barcelona (AMB) and the Salou municipality (Fig. 2). The AMB has one of the largest density population of Europe and very important transport infrastructures, such as an international airport and the port of Barcelona. It consists on the municipality of Barcelona and 35 adjacent municipalities around the city. These urban and peripheral areas sum up a total area of $534.7 \mathrm{~km}^{2}$ and a population 
larger than 3.3 million people. Barcelona concentrates most of the population (1.6 million people in $101.6 \mathrm{~km}^{2}$ ), located between the Besòs and the Llobregat Rivers, the Littoral Range and the Mediterranean Sea (Fig. 2). The two rivers have experienced catastrophic flood events (e.g. September 1971, with 19 deaths and more than 835 Million $€_{2015}$ in direct losses) with return periods higher than 100 years. Most of them are surface water floods, produced by short, local and heavy precipitation events mainly recorded in late summer and autumn.

On the other hand, Salou (Fig. 1) is a small village of the Southern Coast of Catalonia, which population grows exponentially in summer, because of its well-known touristic attractive. Geographically, both regions share features with other Mediterranean regions, with some topographic relief exceeding the $500 \mathrm{~m}$, very close to the coast, with very steep slopes that play an important role in the recurrent floods.

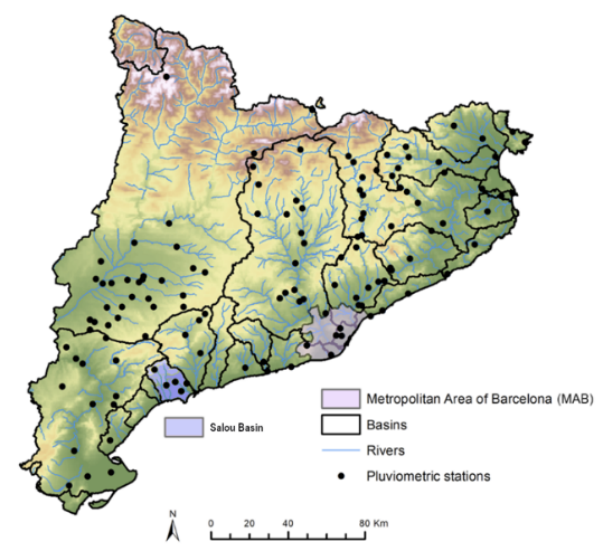

Figure 1. Catalonia, the area of study, where both selected regions are showed, as well as the pluviometric network.

\section{From bottom-up to top-down approaches to floods in Catalonia}

Catalonia has recorded 258 flood events between 1981 and 2015, most of which are surface water floods and flash floods (Cortès et al., 2018). Following a bottom-up approach and classifying floods in categories according to their impacts (Barriendos et al., 2003), they are distributed as follows: 26 of them caused catastrophic impacts, 135 caused extraordinary impacts and 97 caused ordinary impacts. Out of the 117 fatalities produced in this period, 77 people died in catastrophic episodes, with a large percentage being consequence of reckless behaviours (Petrucci et al., 2018). Insurance data from the CCS is only available at municipal scale for the period 1996-2015, for which 436,4 Million $€_{2015}$ has been paid in concept of direct damages by floods in the entire Catalonia, and 83,6 of them correspond to the AMB.

Adopting the top-down approach, floods are usually induced in the area when rainfall exceeds a threshold of $100 \mathrm{~mm} / 24 \mathrm{~h}$, and these events have a return period of less than 10 years. They can be generated by convective and heavy rainfall events, and according to their distribution [Type here]
(Llasat et al., 2007), AMB and Salou are placed in regions where the relative contribution of convective events to total annual precipitation is about $7 \%$. From the total number of convective events, a $11,5 \%$ and $1.9 \%$ for AMB and Salou, respectively, can be classified as "very convective", which means that more than $80 \%$ of the precipitation recorded during the event has overpassed the threshold intensity of $0,8 \mathrm{~mm} / \mathrm{min}$.

Figure 3 shows an integration of the bottom-up and top-down approaches. For each flood category of the entire event (1: extraordinary; 2: catastrophic) the distribution of precipitation in $24 \mathrm{~h}$, maximum precipitation in $30 \mathrm{~min}$, accumulated precipitation in the entire event and economic damages, are represented. According to the analysis, $4 \mathrm{M} €_{2015}$ is a good threshold to separate extraordinary events from catastrophic ones. $75 \%$ of the extraordinary events show accumulated precipitation below $150 \mathrm{~mm}$, threshold that is overpassed by more than $75 \%$ of the catastrophic events. Smaller differences are found in precipitation recorded in $30 \mathrm{~min}$ and $24 \mathrm{~h}$, with mean values are $50 \mathrm{~mm} / 30 \mathrm{~min}$ and $118 \mathrm{~mm} / 24 \mathrm{~h}$ for catastrophic events, and $20 \mathrm{~mm} / 30 \mathrm{~min}$ and $68 \mathrm{~mm} / 24 \mathrm{~h}$ for extraordinary ones. These results, among others, confirm that flash floods producing extraordinary damages, the most common type of floods in this region, are a consequence of intense and short precipitation events, with daily rainfalls of less than $70 \mathrm{~mm}$.

Following this integrated approach Cortès et al. (2017) demonstrated that the economic impacts of a flood event in the AMB are well correlated with the maximum precipitation recorded in $24 \mathrm{~h}$, although it is even better when the time interval is $30 \mathrm{~min}$. If the entire AMB is considered as a unique catchment (the smallest unit of study), a simple logistic regression model can be applied to relate damages and rainfall. This means that each flood event corresponds to a single flood case. Three categories of damages have been considered: (i) total damage (D), (ii) Damage Per Capita (DPC) and (iii) Damage Per unit of Wealth (DPW), that means damage per unit of GDP. These categorizations allow the estimation of the impact of socioeconomic factors on damage, while taking into account population and wealth (Zhou et al., 2017). 

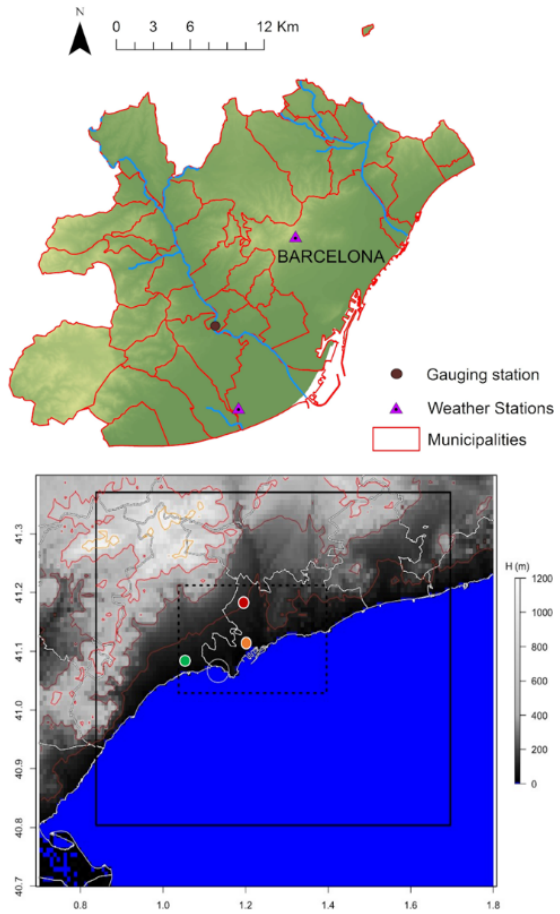

Figure 2. Top: The Metropolitan Area of Barcelona. Bottom: The Salou basin (the color circles represent the three Automatic Weather Stations of the Meteorological Service of Catalonia)

When the analysis is extended to the entire region with the aim to assess flood impacts under future scenarios, it is better to work with a $24 \mathrm{~h}$-interval (Cortès et al, 2018). Cortès et al. (2019) analysed the relationships between flood damage, precipitation and exposure, modelling them by means of a Generalized Linear Mixed Model (GLMM). This type of models permits to deal with the characteristics of the Mediterranean region, which has a complex morphology of mountain chains and strong land-sea contrasts, a dense and growing human population and various environmental pressures. The model allows random effects, besides considering fix predictors related to the hazard and the exposure of the territory.

The GLMM has been applied to all those flood events affecting Catalonia basins for the period that goes from 1996 to 2015. The total amount of cases-basin is 596 (each flood event has as many cases-basin as basins are affected). In 177 of them, an average precipitation higher than $40 \mathrm{~mm}$ was recorded in some point of Catalonia, which is the threshold used in the study to select events (Cortès et al., 2018). It is a regression model where the answer is binary (episode with total damages above a threshold or not). Percentiles are calculated according to the damage's series in each basin. Example: If the 70th percentile is exceeded the answer will be "1", otherwise " 0 ". The result of the model is a probability. An example of the application of the model is shown in Fig. 4, which presents the effect of each explanatory variable in the case of probability exceeding the 70th percentile of damage. For both variables, precipitation and population, this probability sees a fast increase. However, in the case of the second variable a break point around 0.5 million people is observed. From this point, the rate of increase is much lower.

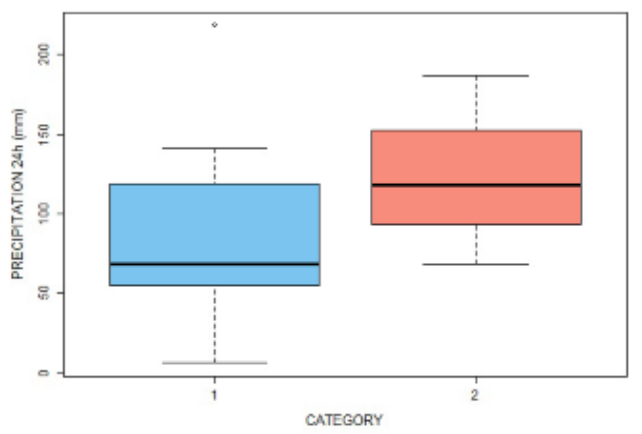

a

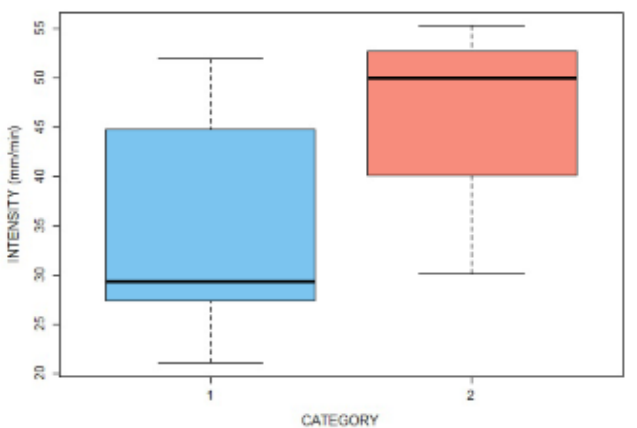

b
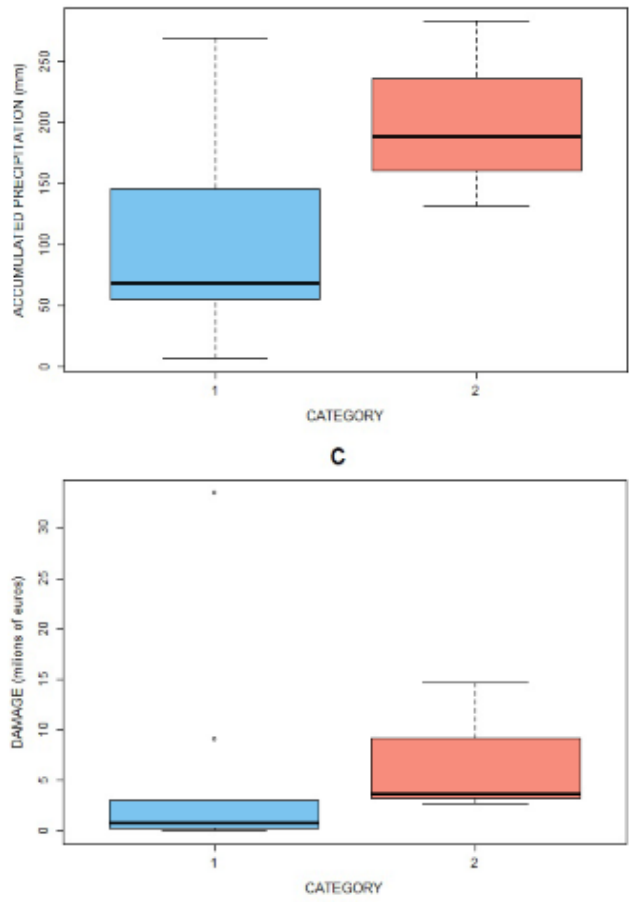

d

Figure 3. Boxplots showing the distribution according to the flood category (blue extraordinary, pink catastrophic): precipitation in $24 \mathrm{~h} \mathrm{(a)}$; precipitation in $30 \mathrm{~min}$ (intensity) (b); accumulated precipitation (c); and damage (d) (adapted from Cortès et al., 2017)

5 Walking towards adaptation 


\subsection{Scenarios of future}

The application of the GLMM technique allows to identify relevant thresholds of different parameters (like precipitation in $24 \mathrm{~h}$ and population) that can be key factors in the analysis of the future measures on damage mitigation associated with flash floods events. This is a necessary tool for regions where the increase of catastrophic floods is expected in the future, In the case of precipitation scenarios, we have used 7 different models of the EUROCORDEX project and taken as reference period 1976-2005. For each model, the year when the global temperature exceeded $1.5,2$, and $3^{\circ} \mathrm{C}$ from pre-industrial levels was obtained, and a 30 -year window centred on that year was taken. For each window it has been selected rainfall days with PPT $>40 \mathrm{~mm} / 24 \mathrm{~h}$. Figure 5 shows that all the models and projections increase the daily precipitation, except for one case. This increase can overpass $10 \%$ of the present maximum daily precipitation.
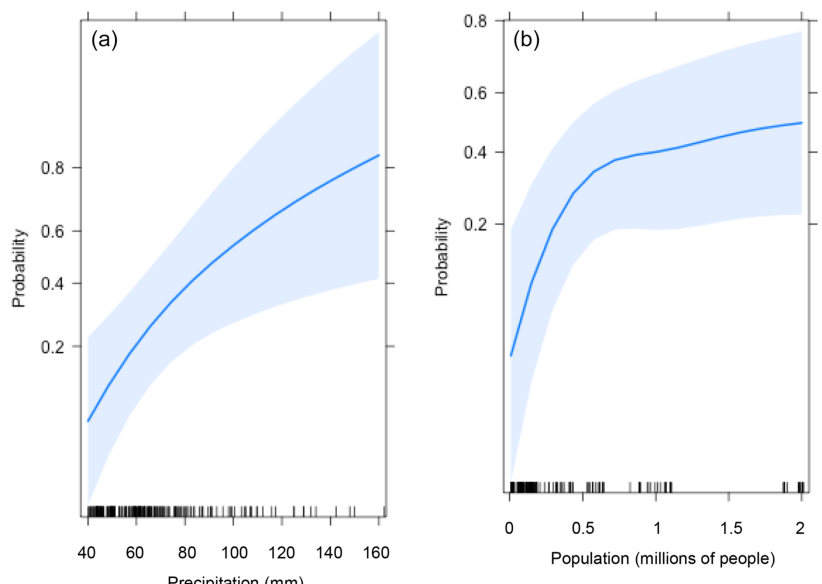

Figure 4. Probability of exceeding the 70th percentile of damage in Catalonia according to the mean precipitation recorded in $24 \mathrm{~h} \mathrm{(a)}$ and to the total population of the basin (b). The best estimates are indicated by solid lines, while the shaded bands indicate the $95 \%$ confidence interval. The black marks at the bottom of each graph indicate the values of the independent variable for each flood case (from Cortès et al., 2019).

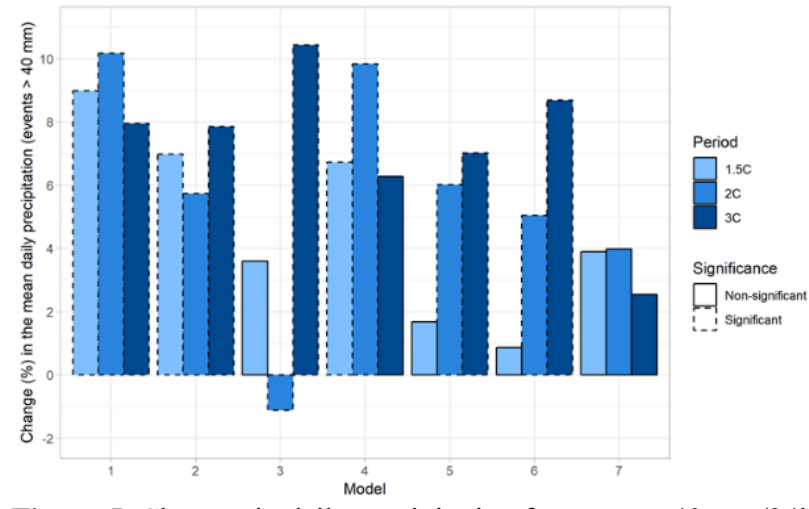

Figure 5. Changes in daily precipitation for events $>40 \mathrm{~mm} / 24 \mathrm{~h}$ (from Cortès et al., 2019).

The combination of the Shared Socioeconomic Pathways (SSPs) with the 2UP model (Van Huijstee et al., 2018) allowed obtaining the total population of the Catalonia for future projections (Fig. 6). Some main treats [Type here] were observed: constant increase of population (SSP5 - the push for economic and social development and the exploitation of abundant fossil fuel resources around the world), moderate increase with a final slight decrease (SSP1, SSP2 and SSP4; sustainable development, middleof-the-road development, and inequality, respectively).

The combination of SSP5 and precipitation scenarios led to an increase probability of damaging events. For instance, in the case of the $70^{\text {th }}$ threshold, the probability would increase a minimum of $40 \%$ for a scenario of $3{ }^{\circ} \mathrm{C}$.

Depending on the real evolution of the population and the changes in the environment, the necessity of applying one or another type of measures will change notably. This is the motivation of this analysis, the identification of weak and strong points of the current Catalan society and the proposal of measures that can help mitigate damages in each of the possible future scenarios. One of these solutions would be to improve flash-flood nowcasting. A second solution, completely different, would be the empowerment of population to cope with floods. Both of them are analysed in the following sections.

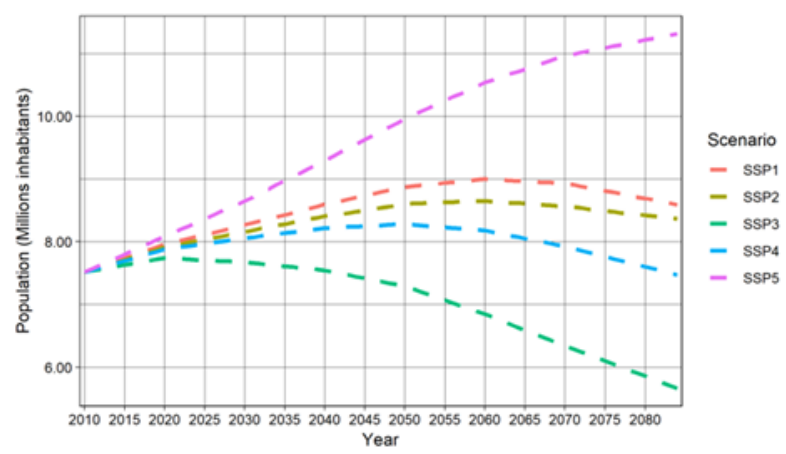

Figure 6. Future population projections for the different SSP's in Catalonia (source: Cortès et al., 2019).

\subsection{Disaster Risk Reduction as adaptation measure}

The Third UN World Conference on Disaster Risk Reduction agreed on The Sendai Framework (18 March 2015) on seven global targets that could be grouped in two classes. The first one refers to a substantial reduction of the global disaster mortality by 2030 , the number of affected people, the direct disaster economic loss, and the disaster damage to critical infrastructure and disruption of basic services. The second one refers to substantially increase the number of countries with national and local disaster risk reduction strategies, international cooperation between countries to complement their national actions, and the access to multi-hazard early warning systems and disaster risk information and assessments to the people. Four Priorities for Action are necessary to achieve these objectives: 1) Understanding disaster risk; 2) Strengthening disaster risk governance to manage disaster risk; 3) Investing in disaster risk reduction for resilience; 4) Enhancing disaster preparedness for effective response and to "Build Back Better" in recovery, rehabilitation and reconstruction. 
The Sendai targets offer a good philosophy to cope with the increase of floods impact, while the priority actions constitute a good strategy pathway. For example, enhancement of disaster preparedness includes various tactics such as distributing flood risk maps, developing media campaigns, signboards, exhibitions, and school education (Nakamura and Llasat, 2017). The tactics should consider the specific features of floods in the region and the main causes of damages.

The first part of this paper has been devoted to Priority 1, "Understanding disaster risk". In synthesis we can conclude that extraordinary floods are very frequent in the coastal region of Catalonia (usually flash-floods and water surface floods); damages are very related to daily and sub-daily precipitation, their increase is expected in future scenarios; and the loss of life is usually due to imprudent behaviours. The second part of the paper will be devoted to the last proposed Action of Sendai "multihazard early warning systems and disaster risk information and assessments to the people", and the $4^{\text {th }}$ Priority: "Enhancing disaster preparedness for effective response and to "Build Back Better" in recovery, rehabilitation and reconstruction.

Following this rationale, these dimensions can be contemplated in the different strategies developed to mitigate natural risks. As an example, the main types of flood strategy and their limitations are shown below.

\section{a) Structural flood protection}

Deflection and retention facilities, check dams, floodcontrol reservoirs, levees, etc.

Main constraints:

- Cost of construction and maintenance

- Impact on ecosystems, landscape

- Collateral impacts: population displacement, cascading effects, critical infrastructures failures

- "Levee effect", "safe development paradox", or "safety dilemma": unintended effects which, paradoxically, seems to increase risk. The increasing flood protection can attract settlements and high-value assets in the areas "protected", due to a sense of complacency, which can dangerously reduce preparedness (Di Baldassarre et al, 2018).

b) Land-use planning and other legal regulations Building codes, mandatory insurances, risk mapping... Main constraints:

- Difficult comprehension of hazard/risk maps

- Urban planning and personal/public interests

- Changes in the price of the soil

- Re-insurance systems that do not favour good practices

\section{c) Emergency Plans}

Emergency plans, coordination civil protection and other operatives, evacuation procedures and maps

Main constraints:

- $\quad$ Lack (or not application) of local planning

- Non-existence of evacuation maps

Historical data and knowledge of past events are one of the best tools to improve risk awareness. They are

${ }^{a}$ Corresponding author: author@e-mail.org

DOI 10.3311/FLOODRisk2020.12.20 useful to risk mapping, identifying vulnerable groups and ranking circumstances in terms of dangerousness, making educational campaigns aiming to promote risk consciousness and defensive behaviours. Increase people's resilience to floods can be done through: educational campaigns, teaching individuals how to behave in the case of flood, and avoiding risky situations, such as driving through floodwater or swimming in a flooded river. This goal involves several subjects: the scientific community, decision-makers, emergency management organization, and, finally, individuals.

Comprehensive flood risk management implies integrated vulnerability analysis plus risk communication plans to inform the population about how they should proceed (or how they should not) when facing a flood event. The participation of the population in the formulation of vulnerability reduction strategies reduces the possible economic damages, increases the efficiency of risk management plans, increases empowerment and increase community resilience. Nowadays, mobile phones and social media are useful to save lives and to alert people on dangerous situations related to floods. Apps's can be useful for developing citizen science (citizens can actively participate in some phase of the research process), as it is the case of FLOODUP (Llasat-Botija et al. 2018), a mobile phone application that provides information on floods, what to do/not to do, and collects data to rebuild flood events.

\subsection{Improving nowcasting in a flash flood prone area}

The success of early warning systems depends on run-off times, communication chain, capacity (time, space, mobility) of people to move to (or remain in) a safe place. The main constraints are the computational and physical modelling limits, the different criteria between different organisms in the same place/region, increasing the initial uncertainty by combining it with the uncertainty of the following processes, and the communication chain.

In Catalonia, there is not an operative flood forecasting system. In turn there is a heavy precipitation warning system. Officially the entity responsible is the Meteorological Service of Catalonia (SMC). When a threshold is exceeded or expected to be exceeded, information is sent to Civil Protection and inserted in weather reports. SMC distinguishes two severity levels and cumulative precipitation over $30 \mathrm{~min}$ and $24 \mathrm{~h}$ : level 1 implies overpass $20 \mathrm{~mm}$ and $100 \mathrm{~mm}$, respectively, and level 2, $50 \mathrm{~mm}$ and $200 \mathrm{~mm}$, respectively. Probabilities are distinguished between low $(<30 \%)$, medium $(>30 \%$ and $<70 \%$ ) and high (>70\%). Rainfall data (1-h resolution) are provided by 165 automatic weather stations from SMC, complemented by a network of four C-band Doppler radars (resolutions $10 \mathrm{~min}$ and $1 \mathrm{kmx} 1 \mathrm{~km}$ ). Twice a day the limited area models WRF, BOLAM and MOLOCH are run, with a resolution of $3 \mathrm{~km}, 9 \mathrm{~km}$ and $27 \mathrm{~km}$. Nowadays, heavy rainfall forecast is done through the combination of these tools.

Salou is one of the main touristic zones in Catalonia due to its beaches. The municipality only has 26,775 
inhabitants (2018) in an area of $15.13 \mathrm{~km}^{2}$, but overnight visits approach nearly 8 million annually. Main urbanistic and touristic settlements are surrounding the local stream (Figure 2), which implies that most of the area presents a potential high-risk flood. An important part of the municipality is built on a flood-prone area, where floods would occur due to in situ and upstream rains. Salou and the surrounding area are the most affected by lightning along the Catalan coast (del Moral et al., 2020), which corroborates the convective behaviour of the weather, and the possibility of having not only heavy rainfalls but also strong winds, hail, and even tornadoes. In addition, the region is also affected by the mesoscale convective systems that episodically cross the Catalan Coast giving place to catastrophic flood events (Rigo et al., 2019).

An improvement of the nowcasting of adverse weather in the region would be a valuable tool to diminish their impacts and save human lives. However, before applying new nowcasting tools it would be necessary to identify the behaviour of convective systems associated to heavy precipitation in the region. To do it, 3D radar cells identification and tracking and the quantitative precipitation estimated (QPE) using radar are the most suitable approaches (del Moral et al., 2020). This allows expanding the knowledge of the meteorological conditions associated to floods, which results in a basic tool to be used as a new adaptative measure for small coastal basins.

The analysis of all convective events recorded in the region along the period 2014-2018, using a new identification and tracking algorithm (del Moral et al., 2018) show that the area is mostly affected by shallow but efficient convection, probably embedded in major weather systems and producing high precipitation rate which tends to saturate the catchments and produce flooding. Topography acts as a triggering factor for storms outside the convective season, as a key feature for the convergence lines organization, and as a capping for stationary cells upstream (del Moral et al., 2020).

Figure 7 shows the high-resolution precipitation field in three flood cases that have affected Salou. It has been obtained using a statistical combination of the radar field and data from the meteorological stations of the SMC. The rainfall field presents large differences between episodes, both in the distribution and in the maximum values over Salou and the surrounding area. In the case of 29 November 2014, the maximum rainfall exceeded $200 \mathrm{~mm}$ in the Pre-littoral chain (more than $1000 \mathrm{~m}$ altitude) affecting the upper part of the catchment. Although convective precipitation cells moved from SE to NW (from sea to inland), it was the mountains what caused stationarity and kept the rain confined over a small area. In the 29 September 2015 case, the maximum values were mainly concentrated along the oriental slope of the mountain (heights lower than $500 \mathrm{~m}$ ) closer to Salou, but again the precipitation recorded over the city was low. The cells movement were chaotic, and a convergence line was created windwards of the mountain range. Finally, in the $10^{\text {th }}$ of October 2018 case, the precipitation was located over the town and surrounding areas. Cells moved from SW to NE, parallel to the coast, and remained stationary over Salou for more than one hour. As it can be seen, the two first cases are examples of floods associated with the [Type here] streams overflow, while on the contrary, the third case was a typical example of water floods by precipitation in situ. Moreover, the effects of all three episodes were further aggravated by the strong sea surf.

In all three cases, significant damage was recorded in Salou. Some of it could have been avoided by having a good associated early warning system that included a nowcasting system capable of distinguishing convective cells, their trajectories and future movements, in order to better detect where the maximum precipitation would occur, the possibility of floods and what response time would there be. It is needed an early warning system that considers fast recognition of convective cells, accounting for the intensity and the motion coupled with the orography. It should be able to set different risk levels depending on two main areas; upstream and downstream of the catchment, since they need different precipitation thresholds, and release weather warnings if the cells are stationary in the same area for a long time. The new 3D identification and tracking tool used here (del Moral et al., 2018) could be applied operatively in the Meteorological Service of Catalonia, being a base tool for an early warning system.

\subsection{Improving population empowerment}

Risk Perception can be improved through information campaigns, information, mass-media, empowerment of the population, and promoting selfprotection. Main constraints are the short memory of past events, the false sensation of security, insufficient public information, different experiences by different individuals or groups within a society, and the lack of knowledge of the territory and adverse weather phenomena. Better resilience to hydrometeorological risks through better knowledge and sensibilization should improve risk perception and individual and social empowerment. Social perception and awareness determine the effectiveness of flood risk mitigation and emergency plans since they enable suitable risk communication and education plans to be devised to improve community resilience (exhibitions, demonstrations, workshops, ...). Participatory and educative projects are an opportunity to improve the awareness and knowledge of the population and their adaptation capacity. This is the case of FLOODUP, a citizen science project that aims to improve the resilience of the population as well as improve the information available to researchers (Llasat-Botija et al, 2019). The aim is to create, in a collaborative way, a map of the main impacts of natural hazards and climate change, as well as areas for improvement and ways communities are adapting. Within the framework of this project an online platform and a Mobile Application has been developed. 

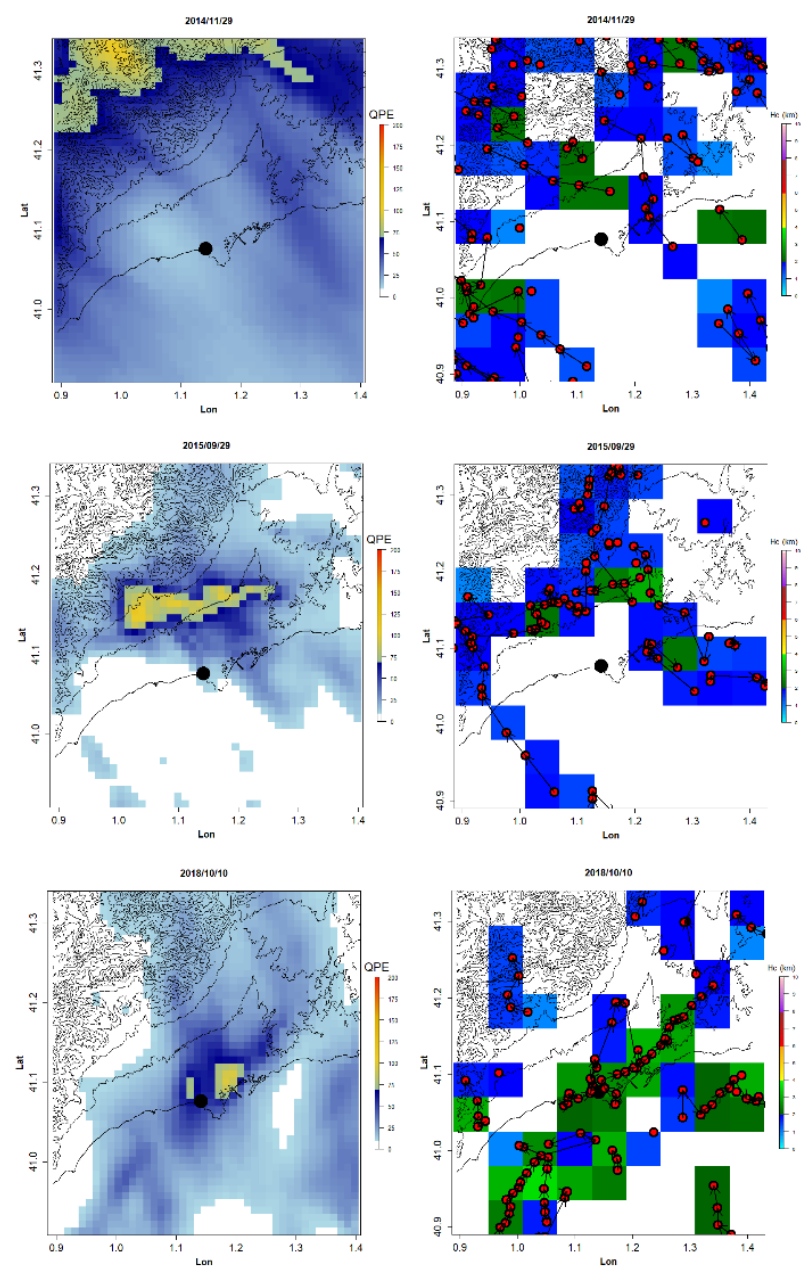

Figure 7. Estimated daily rainfall field $[\mathrm{mm} / 24 \mathrm{~h}]$, resulting from a combination of radar and rain gauges from the SMC (left) and spatial distribution of the totality of convective cells (right) in 24 hours and for the three events: (top) 29 November 2014; (middle) 29 September 2015; and (below) 10 October 2018. The black dot shows the location of Salou. Modified from del Moral et al., 2020.

Through this App, users can provide information on the episodes of floods and the damages caused; observations of bad practices or places that could be particularly affected in the case of floods or other natural hazards; observations related to adaptation, such as traditional local prevention measures, protection infrastructure, or new proposals such as Nature Base Solutions. Besides this, the shared information is useful for the researchers to obtain more data on the resilience and impact and perception of climate change and floods in the region. Parallelly, it is useful to improve public flood awareness.

Up until now, FLOODUP has been used to collect information from different flood events (more than 50) and other phenomena events (more than 30). Thank to this information, an overview of the events that affect the territory has been obtained. Campaigns have also been done to collect information on specific events or places. This has allowed to get further in-situ information for a deeper analysis of these events (or locations), for example identifying the most affected elements, the height of the water in an ungauged river or the prevention measures that have worked. Besides this, these campaigns have included issues that invite the users to discover and reflect on the community's preparation for climate change.

\section{Conclusions}

The present contribution deals with the impacts of floods in present time and future scenarios, and the research to improve the design of adaptation strategies and measures in Catalonia (NE Spanish Mediterranean). Most floods in this region are flash-floods, and impacts are strongly related to precipitation, which is the only variable that can be used from a regional point of view, especially in many ungauged catchments. Combining bottom-up and top-bottom approaches has permitted to define different quantitative thresholds for extraordinary and catastrophic events in terms of hazard (precipitation) and impacts (economic damages).

A Generalized Linear Mixed Model has been applied to obtain the probability of overpassing a threshold of damages based on precipitation and population, for the whole the region of study. The application of this model to future population and precipitation scenarios has showed an increase of the probability of damaging events. This requires new or improved adaptation measures to be implemented in the near future. Relatively new technologies, such as the weather radar, provide databases that are becoming large enough to allow for the identification of new patterns or the confirmation of wellknown ones, with a better spatial and time resolution, as well as an improvement of the early warning systems. On the other hand, new approaches like citizen science could be used to improve the population empowerment when facing floods. The development of initiatives that generate reflective spaces and dialogue, such as the participative project FLOODUP, is a great opportunity to improve the adaptation capacity of the public by empowering them in their self-protection.

The different conditions and their future scenarios (geographic, urbanistic and meteorological), not only of the region of study (Catalonia) but also the whole Mediterranean basin, make these strategies more evident and necessary.

\section{Acknowledgement}

This work in the framework of the M-CostAdapt (CTM2017-83655-C2-1\&2-R) research project, funded by the Spanish Ministry of Economy and Competitiveness (MINECO/AEI/FEDER, UE). 


\section{References}

1. Amaro, J., M. Gayà, M. Aran and M.C. Llasat (2010). Preliminary results of the Social Impact Research Group of MEDEX: The request database (2000-2002) of two Meteorological Services. Nat. Hazards Earth Syst. Sci., 10(12):2643-2652.

2. Barbería, L., J. Amaro, M. Aran, and M.C. Llasat (2014). The role of different factors related to social impact of heavy rain events: considerations about the intensity thresholds in densely populated areas. Nat. Hazards Earth Syst. Sci., 14(7):1843-1852.

3. Barnolas, M. and M. Llasat (2007). Metodología para el estudio de inundaciones históricas en España e implementación de un SIG en las cuencas del Ter, Segre y Llobregat. CEHCEDEX, Monografias M-90, Ministerio de Fomento, Madrid.

4. Barriendos, M., D. Coeur, M. Lang, M.C. Llasat, R. Naulet, F. Lemaitre, A. Barrera (2003). Stationarity analysis of historical flood series in France and Spain (14th-20th centuries). Natural Hazards and Earth System Sciences, 3, 583-592.

5. Blöschl, G., J. Hall, A. Viglione, et al. (2019). Changing climate both increases and decreases European river floods. Nature 573, 108-111. https://doi.org/10.1038/s41586-019-1495-6.

6. Borga, M., E. Gaume, J. D. Creutin, L. Marchi (2008). Surveying flash flood response: gauging the ungauged extremes. Hydrol. Process. 22 (18), 3883-3885.

7. Cortès, M., M. C. Llasat, J. Gilabert, M. LlasatBotija, M. Turco, R. Marcos, J. P. Martín Vide, and L. Falcón (2017). Towards a better understanding of the evolution of the flood risk in Mediterranean urban areas: the case of Barcelona. Natural Hazards, pp. 1-22.

8. Cortès, M., M. Turco, M. Llasat-Botija, and M. C. Llasat (2018): The relationship between precipitation and insurance data for floods in a Mediterranean region (northeast Spain), Nat. Hazards Earth Syst. Sci., 18, 857-868, https://doi.org/10.5194/nhess-18-857-2018.

9. Cortès, M., M. Turco, P. Ward, J. A. SánchezEspigares, L. Alfieri, and M.C. Llasat (2019) Changes in flood damage with global warming on the eastern coast of Spain, Nat. Hazards Earth Syst. Sci., 19, 2855-2877, https://doi.org/10.5194/nhess-19-2855-2019.

10. CRED-UNISDR, 2015. The Human Cost of Weather-Related Disasters 1995-2015. https://www.unisdr.org/files/46796 cop21weath erdisastersreport2015.pdf

11. Del Moral, A., T. Rigo, M. C. Llasat (2018). A radar-based centroid tracking algorithm for severe weather surveillance: identifying split/merge processes in convective system. Atmospheric Research, 213, 110-120. 0169-8095

12. Del Moral, A., M. C. Llasat and T. Rigo (2020). Connecting flash flood events with radar-derived convective storm characteristics on the northwestern Mediterranean coast: knowing the present for better future scenarios adaptation. Atmospheric Research, 238,1 July 2020, 104863https://doi.org/10.1016/ j.atmosres.2020.104863

13. Di Baldassarre G, H. Kreibich, S. Vorogushyn, J. Aerts, K. Arnbjerg-Nielsen, M. Barendrecht, P. Bates, M. Borga, W. Botzen, P. Bubeck, B. De Marchi, C. Llasat, M. Mazzoleni, D. Molinari, E. Mondino, J. Mård, O. Petrucci, A. Scolobig, A. Viglione, P. J. Ward (2018) Hess opinions: an interdisciplinary research agenda to explore the unintended consequences of structural flood protection. Hydrol Earth Syst Sci 22:5629-5637. https://doi.org/10.5194/hess-22-5629-2018

14. Dottori, F., M. L. V. Martina, and R. Figueiredo (2018). A methodology for flood susceptibility and vulnerability analysis in complex flood scenarios. Journal of Flood Risk Management, 11:632-645.

15. Elmer, F., A.H. Thieken, I. Pech, and H. Kreibich (2010). Influence of flood frequency on residential building losses. Nat. Hazards Earth Syst. Sci., , 10(10):2145-2159

16. Escuder-Bueno, I., J. T. Castillo-Rodriguez, S. Zechner, C. Jöbstl, S. Perales-Momparler, and G. Petaccia (2012). A quantitative flood risk analysis methodology for urban areas with integration of social research data. Nat. Hazards Earth Syst. Sci., 12(9):2843-2863.

17. Field, C. B., V. Barros, T. F. Stocker and Q. Dahe (2012). Managing the risks of extreme events and disasters to advance climate change adaptation: special report of the intergovernmental panel on climate change. Cambridge University Press.

18. Gain, A. K., V. Mojtahed, C. Biscaro and S. Balbi (2015). An integrated approach of flood risk assessment in the eastern part of Dhaka City. Natural Hazards, 79(3):1499-1530.

19. Garcia, L. E., J. H., Matthews, D. J. Rodriguez, M. Wijnen, K. N. DiFrancesco and P. Ray (2014). Beyond downscaling: a bottom-up approach to climate adaptation for water resources management. World Bank Group, Washington, DC.

20. Gaume, E., M. Borga, M.C. Llasat, S. Maouche, M. Lang and M. Diakakis (2016). Mediterranean extreme floods and flash floods. Into Hydrometeorological extremes, chapter 3, The Mediterranean Region under Climate Change. A Scientific Update (coordinated byAllEnvi).133- 
144. IRD Éditions Institut de Recherche pour le Développement, Marseille, 2016, ISBN : 978-27099-2219-7.

21. Hall, J., B. Arheimer, M. Borga, R. Brázdil et al. (2014). Understanding Flood Regime Changes in Europe: A state of the art assessment. Hydrol. Earth Syst. Sci., 18, 2735-2772, 2013, www.hydrol-earth-syst-sci.net/18/2735/2014/ doi:10.5194/hess-18-2735-2014.

22. Kreibich, H., S. Vorogushyn, J.C.J.H. Aerts, H. Apel, G.T. Aronica, K. Arnbjerg-Nielsen, G. Di Baldassarre, L.M. Bouwer, P. Bubeck, T. Caloiero, D.T. Chinh, M. Cortés, A.K. Gain, V. Giampá, C. Kuhlicke, Z.W. Kundzewicz, M.C. Llasat, J. Mård, P. Matczak, M. Mazzoleni, D. Molinari, N.V. Dung, O. Petrucci, K. Schröter, K. Slager, A.H. Thieken, P.J. Ward, B. Merz (2017). Adaptation to flood risk - results of international paired flood event studies. Special collection "Avoiding Disasters: Strengthening Societal Resilience to Natural Hazards" in the journal Earth's Future. Earth's Future,5,953-965, doi:10.1002/2017EF000606

23. Llasat, M.C., M. Ceperuelo and T. Rigo, 2007: Rainfall regionalization on the basis of the precipitation convective features using a raingauge network and weather radar observations. Atmospheric Research, 83, 415426.

24. Llasat, M. C., M. Llasat-Botija and L. López (2009). A press database on natural risks and its application in the study of floods in Northeastern Spain. Nat. Hazards Earth Syst. Sci., , 9(6):20492061.

25. Llasat, M. C., M. Llasat-Botija, O. Petrucci, A.A. Pasqua, J. Rosselló, F. Vinet, L. Boissier (2013a). Floods in the North-Western Meditrerranean Region : presentation of the HYMEX database and comparison with pre-existing global databases. La Houille Blanche, January 2013, 1, 5-9, DOI 10.1051/lhb/2013001

26. Llasat, M. C., M. Llasat-Botija, O. Petrucci, A. A. Pasqua, J. Rosselló, F. Vinet and L. Boissier (2013b). Towards a database on societal impact of Mediterranean floods within the framework of the HYMEX project. Nat. Hazards Earth Syst. Sci., , 13(5):1337-1350.

27. Llasat, M. C., R. Marcos, M. Turco, J. Gilabert and M. Llasat-Botija (2016). Trends in flash flood events versus convective precipitation in the Mediterranean region: The case of Catalonia. Journal of Hydrology, 541(September 2002):2437.

28. Llasat-Botija, M., M. Cortès, M. C. Llasat (2019). The Use of Citizen Information in Post-event Analysis of Flash Floods in Catalonia, Retours d'expériences post-catastrophes naturelles, Géorisques.

29. Merz, B., S. Vorogushyn, S. Uhlemann, J. Delgado and Y. Hundecha (2012). HESS Opinions "More efforts and scientific rigour are needed to attribute trends in flood time series", Hydrol. Earth Syst. Sci., 16, 1379-1387, doi:10.5194/hess-16-1379- 2012, 2012

30. Merz, B., H. Kreibich and U. Lall (2013). Multivariate flood damage assessment: A tree-based data-mining approach. Nat. Hazards Earth Syst. Sci., , 13(1):53-64.

31. Montanari, A., G. Young, H. H. G. Savenije, et al. (2013) Panta Rhei-Everything Flows":Change in hydrology and society-The IAHS Scientific Decade 2013-2022, Hydrological Sciences Journal, 58:6, 1256-1275, DOI:10.1080/02626667.2013.809088.

32. Nakamura, I. and M.C. Llasat (2017). Policy and systems of flood risk management: a comparative study between Japan and Spain. Natural Hazards. 87: 919, doi:10.1007/s1 1069-017-2802-x Impact

33. Nasiri, H. and S. Shahmohammadi-Kalalagh (2013). Flood vulnerability index as a knowledge base for flood risk assessment in urban area. Journal of Novel Applied Sciences, 2(8):269-272.

34. Neumayer, E. and F. Barthel (2011). Normalizing economic loss from natural disasters: A global analysis. Global Environmental Change, 21(1):13-24.

35. Papagiannaki, K., K. Lagouvardos, V. Kotroni and A. Bezes (2015). Flash flood occurrence and relation to the rainfall hazard in a highly urbanized area. Nat. Hazards Earth Syst. Sci., , 15, 1859-1871, https://doi.org/10.5194/nhess15-1859-2015, 2015

36. Petrucci, O. and A. A. Pasqua (2009). A methodological approach to characterise Landslide Periods based on historical series of rainfall and landslide damage. Nat. Hazards Earth Syst. Sci. 9(5):1655-1670.

37. Petrucci, O., A. A. Pasqua and M. Polemio (2012). Flash flood occurrences since the 17th century in steep drainage basins in southern Italy. Environmental Management, 50(5):807-818.

38. Petrucci, O. (2013). Brief communication: The assessment of damage caused by historical landslide events. Nat. Hazards Earth Syst. Sci, 13(3):755-761.

39. Petrucci, O., L. Aceto, C. Bianchi, V. Bigot, R. Brázdil, S. Pereira, A. Kahraman, Ö. Kılıç, V. Kotroni, M.C. Llasat, M. Llasat-Botija, K. Papagiannaki, A. A. Pasqua, J. Řehoř, J. Rossello Geli, P. Salvati, F. Vinet, J. L. Zêzere (2019). Flood Fatalities in Europe, 1980-2018: Variability, Features, and Lessons to Learn. Water 2019, 11, 1682; doi:10.3390/w11081682 
40. Rigo, T., M. Berenguer, M. C. Llasat (2019). An improved analysis of Mesoscale Convective Systems in the Western Mediterranean using Weather Radar. Atmospheric Research. October 2019, vol. 227, 146-157. https://doi.org/10.1016/j.atmosres.2019.05.001

41. Schröter, K., H. Kreibich, K. Vogel, C. Riggelsen, F. Scherbaum and B. Merz (2014). How useful are complex flood damage models? Water Resources Research, 50(4):3378-3395.

42. Thieken, A. H., M. Müller, H. Kreibich, and B. Merz (2005). Flood damage and influencing factors: New insights from the August 2002 flood in Germany. Water Resources Research, 41(12):1-16.

43. Tramblay, Y., S. Somot (2018). Future evolution of extreme precipitation in the Mediterranean. Climatic Change, 151:289-302 https://doi.org/10.1007/s10584-018-2300-5.

44. Van Huijstee, J., B. van Bemmel, A. Bouwman and F. van Rijn (2018). Towards an Urban Preview: Modelling future urban growth with 2UP. Technical report, PBL Netherlands Environmental Assessment Agency, The Hague

45. Zhou, Q., G. Leng, and L. Feng (2017). Predictability of state-level flood damage in the conterminous United States: the role of hazard, exposure and vulnerability. Scientific Reports, 7(1):5354. 